\title{
The Impact of Covid-19 on Pencak Silat Course Process in STKIP PGRI Bangkalan
}

\author{
Heni Yuli Handayani* \\ Program Studi Pendidikan Olahraga STKIP PGRI Bangkalan, Indonesia \\ * heni@stkippgri-bkl.ac.id
}

\begin{abstract}
Indonesia is a country affected by the spread of COVID-19. Therefore, the government has implemented online lectures as an effort to reduce the spread of COVID-19 in Indonesia. One of the lectures affected by COVID-19 is the pencak silat course. This study aims to analyze the impact of the COVID-19 pandemic on the learning process of the pencak silat course at STKIP PGRI Bangkalan. This research uses an exploratory case study method and a quantitative case study approach which is used to obtain information about the impact of the COVID-19 pandemic on the STKIP PGRI Bangkalan pencak silat course. The sampling technique in this study was carried out with saturated sampling, obtained a sample of 30 students of the 2017 class of Sport Education STKIP PGRI Bangkalan. The data collection technique used in this study was a survey technique in the form of a questionnaire using google forms. Validity test shows that all items of the variables used are declared valid with a value of $r>0.355(n=31)$. The validity test shows that the Cronbach Alpha coefficient value of each $>0.6$, it can be said that the questionnaire in this study is reliable. Descriptive test shows that students agree with the percentage of P1 83.3\%, P2 80\%, P3 80\%, P4 90\%, P5 90\%, P6 83.3\%, P7 76.7\%, P8 86.7\%, P9 83.3\%, P10 80\%, P11 83.3 \%, P12 86.7\%, P13 83.3\%, P14 80\%, P15 83.3\%, P16 80\%, P17 80\%, P18 83.3\%, P19 80\%, P20 90\%. The results of this study indicate that the majority of students agree that COVID-19 has an impact on the pencak silat lecture process, besides that there are also several obstacles experienced by students in the process of lecturing online pencak silat courses. Based on the results of the study, it can be concluded that CIVID-19 has an impact on the learning process of the STKIP PGRI Bangkalan pencak silat course.
\end{abstract}

Keywords: Lecture Process, COVID-19 Pandemic, Pencak Silat 


\section{STRADA Jurnal Ilmiah Kesehatan}

DOI: $10.30994 /$ sjik.v9i2.508

ISSN: 2252-3847 (print); 2614-350X (online)

Vol.9 No.2 November 2020 Page. 1611-1616

\section{BACKGROUND}

The world is being hit by an outbreak of the corona virus (SARS-CoV-2) and it is called the 2019 coronavirus disease (COVID-19) (WHO, 2020). COVID-19 is a viral infection that has resulted in 90,308 people being infected as of March 2, 2020 (Yuliana, 2020). This virus originated from Wuhan China, which was found at the end of December 2019. Until now, it has been confirmed that there are 65 countries that have contracted this one virus (WHO, 2020). Indonesia is the second country with the highest spread of COVID19 with an increase of over 1000 . Indonesia ranks 31 out of 40 countries with the highest number of cases in the world. This is a health problem for the world, especially Indonesia (Mastura and Santaria, 2020).

The COVID-19 pandemic is a devastating disaster for all people in the world. All segments of human life in the world are disturbed (Mastura and Santaria, 2020). In Indonesia, COVID-19 has caused the government to implement a Large-Scale Social Restriction (PSBB) policy in several areas. This policy changed the socio-economic activities of the community, such as limited transportation, shopping centers, recreation and entertainment venues. This situation has a broad impact on the socio-economic conditions of the community, including job security and a decrease in workers' income (Ngadi et al., 2020). In the early phase the International Labor Organization (ILO) estimated that around 25 million jobs worldwide could be lost due to the COVID-19 pandemic (ILO, 2020a). Furthermore, in the second quarter of 2020 the ILO predicts the working hours of all workers will decrease by 10.5 percent or the equivalent of 305 million full-time workers assuming full-time working hours is 48 hours per week (ILO, 2020c). Educational institutions are temporarily closed, this is an effort to contain the spread of the COVID-19 epidemic around the world which affects millions of students, not except in Indonesia. Disturbances in the direct learning process between students and teachers and the cancellation of learning assessments have an impact on the psychology of students and decrease the quality of student skills. This burden is the responsibility of all elements of education, especially the state in facilitating the continuity of schools for all educational stakeholders in order to carry out distance learning. How should Indonesia plan, prepare for, and overcome the recovery of COVID-19, to reduce losses in the world of education in the future (Aji, 2020).

The impact of COVID-19 is also experienced in the world of education (Aji, 2020). In the world of education, COVID-19 has a big impact on teachers, students and parents. The closure of educational activities is the government's effort to reduce the rate of spread of COVID-19. The government took steps to close schools, but also took steps so that the learning process was not left behind and students still received the right to gain knowledge. Ok, because of that, the government decided that the learning process would continue but not face-to-face but online. Due to the high spread of COVID-19 in Indonesia, schools were closed, and universities were no exception. So that lectures are conducted online (Simmons 2002).

The learning process on campus is the best public policy tool as an effort to increase knowledge and skills. In addition, many students think that lectures are a very fun activity, they can interact with each other. Lectures can also improve social skills and social class awareness of students. Lecture as a whole is a medium of interaction between students and lecturers to improve their abilities, skills and affection between them. However, until now college has stopped suddenly due to interference from COVID-19 (Mastura and Santaria, 2020).

In sports education lectures, one of the subjects affected by COVID-19 is the pencak silat course. Pencak silat is a product of Indonesian society and includes the culture of the 


\section{STRADA Jurnal Ilmiah Kesehatan}

DOI: $10.30994 /$ sjik.v9i2.508

ISSN: 2252-3847 (print); 2614-350X (online)

Vol.9 No.2 November 2020 Page. 1611-1616

Malay family. The Malay family is basically an agrarian society and a community community, so the culture that underlies or results is the culture of the association. Community culture is the culture of mutual cooperation, kinship, kinship, togetherness, solidarity, harmony, and social tolerance (Kriswanto, 2015). The ideal goal of education through the sport of pencak silat is also comprehensive because it includes not only physical aspects, but also other aspects that contain moral, social and emotional aspects. Pencak silat as part of the Indonesian nation's culture has developed in line with the history of Indonesian society (Junianto, 2013).

Research conducted by Aji (2020) states that COVID-19 has an impact on the world of education in Indonesia. Mastura and Santaria (2020) based on their research show that the COVID-19 pandemic has an impact on the teaching process for teachers and students. According to Fauziyah (2020) that COVID-19 has an impact on the effectiveness of online learning in Islamic Education. However, the impact of COVID-19 on the teaching process of the pencak silat course is still unclear. On the basis of the background of the problems above, the aim of this study is to analyze the impact of the COVID-19 pandemic on the lecture process of the pencak silat course.

\section{METHODS}

This research uses an exploratory case study method and a quantitative case study approach which is used to obtain information about the impact of the COVID-19 pandemic on current teaching and learning activities at the STKIP PGRI Bangkalan campus. The sampling technique in this study was carried out with saturated sampling, where all members of the population were used as samples, thus the samples taken in this study were all students of 2017 Sports Education as members of the population, amounting to 31. survey in the form of a questionnaire. The questionnaire uses google form and the list of questions is compiled to be developed based on related literature. The results of the questionnaire were analyzed statistically using packet statistical software for social science (SPSS). Analysis using SPSS, the first is the validity test, followed by the reliability test using the Cronbach Alpha Coefficient, and the last one uses the descriptive test.

\section{RESULTS}

The data collected from the first questionnaire were analyzed through the validity test as follows.

\section{Table 1. Validity Test Table}

\begin{tabular}{cccc}
\hline Quetions & r-count & p-value & Information \\
\hline 1 & 0,932 & 0,000 & Valid \\
\hline 2 & 0,433 & 0,015 & Valid \\
\hline 3 & 0,492 & 0,005 & Valid \\
\hline 4 & 0,372 & 0,040 & Valid \\
\hline 5 & 0,829 & 0,000 & Valid \\
\hline 6 & 0,569 & 0,000 & Valid \\
\hline 7 & 0,637 & 0,000 & Valid \\
\hline 8 & 0,882 & 0,000 & Valid \\
\hline 9 & 0,924 & 0,000 & Valid \\
\hline 10 & 0,587 & 0,001 & Valid \\
\hline 11 & 0,802 & 0,000 & Valid
\end{tabular}




\section{STRADA Jurnal Ilmiah Kesehatan}

DOI: $10.30994 /$ sjik.v9i2.508

ISSN: 2252-3847 (print); 2614-350X (online)

Vol.9 No.2 November 2020 Page. 1611-1616

\begin{tabular}{llll}
\hline 13 & 0,924 & 0,000 & Valid \\
\hline 14 & 0,630 & 0,000 & Valid \\
\hline 15 & 0,586 & 0,001 & Valid \\
\hline 16 & 0,485 & 0,006 & Valid \\
\hline 17 & 0,832 & 0,000 & Valid \\
\hline 18 & 0,932 & 0,000 & Valid \\
\hline 19 & 0,882 & 0,000 & Valid \\
\hline 20 & 0,864 & 0,000 & Valid \\
\hline
\end{tabular}

Table 1 The validity test shows that all items of the variables used were declared valid with a value of $r>0.355(n=31)$ or a $p$-value $<0.05$. After the validity test continued with the reliability test.

Table 2 Reliability Test

\begin{tabular}{cccc}
\hline Variabel & Quetions & $\begin{array}{c}\text { Koefisien Alpha } \\
\text { Cronbach }\end{array}$ & Information \\
\hline $\begin{array}{c}\text { The Impact of Covid-19 no Pencak Silat } \\
\text { Course Process }\end{array}$ & 20 & 0,952 & Reliabel \\
in Stkip Pgri Bangkalan & & & \\
& & &
\end{tabular}

Table 2 shows that the questionnaire on "The Impact of the COVID-19 Pandemic on the 2020 STKIP PGRI Bangkalan Pencak Silat Course Process" used in this study had a Cronbach Alpha coefficient value of $>0.6$ each, so it can be said that the questionnaire in this study has reliable. If the data shows valid and reliable, it will be followed by descriptive analysis as follows.

Table 3 Descriptive Test

\section{Quetions Percentage of Approval Rate for Answers}

\begin{tabular}{cc}
\hline P1 & $83.3 \%$ \\
\hline P2 & $80 \%$ \\
\hline P3 & $90 \%$ \\
\hline P4 & $90 \%$ \\
\hline P5 & $83.3 \%$ \\
\hline P6 & $76.7 \%$ \\
\hline P7 & $86.7 \%$ \\
\hline P8 & $83.3 \%$ \\
\hline P9 & $80 \%$ \\
\hline P10 & $83.3 \%$ \\
\hline P11 & $86.7 \%$ \\
\hline P12 13 & $83.3 \%$ \\
\hline P13 & $80 \%$ \\
\hline P14 15 & $83.3 \%$ \\
\hline
\end{tabular}




\section{STRADA Jurnal Ilmiah Kesehatan}

DOI: $10.30994 /$ sjik.v9i2.508

ISSN: 2252-3847 (print); 2614-350X (online)

Vol.9 No.2 November 2020 Page. 1611-1616

\begin{tabular}{lc}
\hline P16 & $80 \%$ \\
\hline P17 & $80 \%$ \\
\hline P18 & $83.3 \%$ \\
\hline P19 & $80 \%$ \\
\hline P20 & $90 \%$ \\
\hline
\end{tabular}

Table 3 shows the percentage of students who agree 76.7\% - 90\% that COVID-19 has an impact on STKIP PGRI Bangkalan pencak silat courses.

\section{DISCUSSION}

This study aims to analyze the impact of the COVID-19 pandemic on the learning process of the pencak silat course at STKIP PGRI Bangkalan. Based on the research results, it shows that the COVID-19 pandemic has an impact on the learning process of the pencak silat course at STKIP PGRI Bangkalan. This is in accordance with research conducted by Mastura and Santaria (2020) based on their research showing that the COVID-19 epidemic has an impact on the teaching process for teachers and students. The impact of the spread of COVID-19 has led to the implementation of online or online learning (Fauziyah, 2020). Online or online learning is learning based on technology in which learning materials are sent electronically to students remotely using a computer network. The government says that online learning is the most effective way to do learning in the Covid-19 pandemic era. However, this online learning has many complaints from students. This is because online learning is less effective (Amirudin, 2019). One of the impacts that occur due to COVID-19 on lectures is on students, lecturers, and parents. Students attend lectures in class and in the field with an atmosphere with many friends. However, the consequences of COVID-19 must be inversely proportional to carrying out lectures online from their homes. Regarding the ability factor, of course each student has different abilities, so that it will be different in understanding each student (Mastura and Santaria, 2020). This affects the ability of students to access various information which will result in the progress of the world in general and the world of education in particular (Amirudin, 2019). Of course, this will also affect student achievement and motivation in lectures. In addition, the impact of COVID-19 on students can also make students feel anxious. If students have emotional intelligence, they will be able to control their emotions, and when they attend lectures they will be more enthusiastic. The effectiveness of online or online lectures depends on the technology, the character of the teacher, and the characteristics of the student. Online lectures in the middle of a social distancing situation are also constrained by bad networks, inadequate facilities and infrastructure, lecturers who are not yet proficient in using technology and social media as learning media in the implementation of lectures (Fauziyah, 2020). In addition, because of this pandemic, students are lacking in preparation, which makes students bored and bored, making them want to leave the house (Mastura and Santaria, 2020). The impact of COVID19 is also experienced by parents of students who carry out recovery activities online. Parents again get additional assignments and at the same time become teachers for their children during the online learning process. Parents are required to guide and supervise their children during the online learning process. In this era of the COVID-19 pandemic, the responsibilities and roles of parents in children's learning are very influential because some of the duties of the teacher have been carried out by the parents. This is because students carry out lectures from home so that the role of parents in supervising and guiding is very much needed (Mastura and Santaria, 2020). 


\section{STRADA Jurnal Ilmiah Kesehatan}

DOI: $10.30994 /$ sjik.v9i2.508

ISSN: 2252-3847 (print); 2614-350X (online)

Vol.9 No.2 November 2020 Page. 1611-1616

\section{CONCLUSION}

The COVID-19 pandemic has an impact on the learning process of the pencak silat course at STKIP PGRI Bangkalan. The impact that occurs is experienced by students, lecturers, and also parents. In addition, it also has an impact on motivation and achievement, this is due to the limitations of students in accessing information, constrained by bad networks, inadequate facilities and infrastructure, lecturers who are not proficient in using technology and social media as learning media, students are bored and bored with lectures. on line. Based on the results of the research, it is suggested to carry out further research on other subjects to find out the comparison between the subjects there are similarities or there are differences.

\section{REFERENCES}

Aji, R.H.S. (2020). Dampak Covid-19 pada Pendidikan di Indonesia: Sekolah, Keterampilan, dan Proses Pembelajaran. Jurnal Sosial dan Budaya, 7(5): 395402. DOI: $\quad 10.15408 /$ sjsbs.v7i5.15314.

Fauziyah, N. (2020). Dampak Covid-19 Terhadap Efektivitas Penbelajaran Daring Pendidikan Islam. Jurnal Al-Mau'izhoh, 2(2): 1-11.

International Labour Organization (ILO). (2020a). COVID-19 dan world of work: Impact and policy responses. Geneva: International Labour Organization.

International Labour Organization (ILO). (2020c). ILO monitor: Covid-19 and the world of work (3 nd ed.). Geneva: International Labour Organization.

Kriswanto, E.S. (2015). Pencak Silat: Sejarah dan Perkembangan Pencak Silat, Taknikteknik dalam Pencak Silat, Pengetahuan Dasar Pertandingan Pencak Silat. Pustaka Vari Press: Yogyakarta.

Mastura, dan Rustan Santaria. (2020). Dampak Pandemi Covid-19 terhadap Proses Pengajaran bagi Guru dan Mahasiswa. Jurnal Studi Guru dan Pembelajaran 3(2): 289-295. https://doi.org/10.30605/jsgp.3.2.2020.293.

Ngadi, Meilianna, R., Purba, Y.A. (2020). Dampak Pandemi COVID-19 Terhadap PHK dan Pendapatan Pekerja Di Indonesia. Jurnal Kependudukan Indonesia, 43-48.

Junianto, R.D. (2013). Motivasi Mahasiswa Mengikuti Kegiatan Ekstrakurikuler Pencak Silat pada Mahasiswa Kelas VIII SMP Negeri 27 Kabupaten Batanghari. Jurusan Pendidikan Olahraga dan Kesehatan, FKIP Universitas Jambi: Skripsi.

Simmons, D. E. (2002). The Forum Report: E-learning Adoption Rates and Barriers. The ASTD e-Learning Handbook, 19-23.

WHO. (2020). WHO Director-generals remaks at the media briefing on 2019-nCoV on 11 oktober 2020. Cited okt 13rd 2020.available on: https://www.who.int/dg/speeches/detail/who-director-generals-remaks-at-themedia briefing-on-2019-ncov-11oktober-2020 (oktober12th 2020).

Yuliana. (2020). Corona Virus Diseases (COVID-19); Sebuah Tinjauan Literatur. Wellness And Healthy Magazine, 2(1): 187-192. 